\title{
The ankle injury-indications for the selective use of X-rays
}

\author{
T. Vargish and W. R. Clarke \\ Departments of Surgery and Preventive Medicine University of lowa School of Medicine, \\ lowa City
}

\section{R. A. Young}

Department of Surgery, University of Michigan College of Medicine, Ann Arbor

\author{
A. Jensen \\ Sisters of Mercy Health Corporation, Farmington Hills, Michigan
}

\begin{abstract}
Summary
The radiograph is rapidly superseding the clinical examination as the diagnostic tool for acute ankle injuries. Twenty-four independent variables which might help distinguish between soft tissue injuries and fractures at the ankle were identified and then used prospectively to study 150 consecutive patients with ankle injuries. Nineteen patients had fractured ankles ( 12.7 per cent) and 131 (87.3 per cent) had soft tissue injuries. Only the patient's ability to bear weight on the injured ankle and the presence of tenderness over the lateral aspect of the ankle below the malleolus proved to be helpful. When these 2 signs were present together, regardless of all other variables, there was a 97.5 per cent probability of soft tissue injury $P<0.005)$. This study suggests that careful patient assessment will permit more discriminating use of ankle $\mathrm{X}$-rays.
\end{abstract}

\section{INTRODUCTION}

THE injured ankle is one of the most common conditions seen in the Emergency Department and the examining doctor frequently includes the ankle's radiograph as a major part of the patient's assessment. One report suggests that these films may account for 10 per cent of the total number of $X$-ray studies made in the Emergency Department (de Lacy and
Bradbrooke, 1979). A number of clinical reviews have attempted to establish guidance for the selective use of $\mathrm{X}$-rays in diagnosing ankle injuries (Garfield, 1960; Stother, 1974; de Lacy and Bradbrooke, 1979; Brooks et al., 1981; Brand et al., 1982). Unfortunately, none of these reports has employed statistical analysis to support their proposed guidance.

In a retrospective review of over 600 patients with ankle injuries during the past 2 years, fewer than 25 per cent had adequate clinical evaluation and almost all of them ( $>99$ per cent) had radiographs. Seventy-three fractures of the ankle (12 per cent) were diagnosed. From this review, 24 variables were chosen which appeared to be helpful in evaluating ankle injuries. These variables were incorporated into an assessment form which was subsequently used in the following prospective study.

\section{PATIENTS AND METHODS}

Over a six month period, 150 consccutive patients were examined for ankle injuries, using the assessment form just described, before X-ray examination. The variables used in the study included those relevant to the history of the injury 
Table I. Factors related to the history of injury

Right or left foot

Manner of arrival at hospital.

Ability to bear weight on ankle after injury

Onset of pain immediately after injury

Popping or cracking sound at the time of injury

Mechanism of injury

Direction of injury

Time from injury to arrival at hospital.

Activity at time of the injury

Table III. Distribution of injuries by age

\begin{tabular}{lcc}
\hline $\begin{array}{l}\text { Age } \\
\text { Group }\end{array}$ & No. of Fractures & $\begin{array}{c}\text { No. of Soft } \\
\text { Tissue Injuries }\end{array}$ \\
\hline $1-10$ & 0 & 3 \\
$11-20$ & 6 & 37 \\
$21-30$ & 6 & 67 \\
$31-40$ & 2 & 11 \\
$41-50$ & 2 & 4 \\
$51-60$ & 2 & 5 \\
$61-70$ & 1 & 1 \\
\hline
\end{tabular}

(Table $I$ ) and the findings at the time of examination (Table II).

The ability to distinguish fracture from soft tissue injury was determined for each variable using chi-squared analysis. $P$-values of less than 0.05 indicated that the variable contributed significantly in distinguishing fractures from soft tissue injuries of the ankle. The relative merit of each variable can be measured by determining the increase over chance in the probability of having a soft tissue injury. This is reported as 'gain over chance' and represents the probability of soft tissue injury for a given variable, minus chance probability (in our study 87.3 per cent). A positive difference indicates a greater likelihood of soft tissue injury; a negative difference indicates a greater likelihood of fracturc.

Using higher order contingency tables and $\log$ linear models, those variables that contributed significantly to the differentiation of soft tissue injury from fracture were combined. Numerous models were examined and only the model which contributed most usefully, irrespective of all other variables, is represented here.

\section{RESULTS}

Among the 150 patients, there were 19 fractures
Table /I. Findings at the time of the physical examination

\author{
Ability to bear weight on the injured ankle \\ Location of ankle swelling \\ Degree of swelling \\ Presence of ecchymosis \\ Laceration of skin \\ Location of pain on palpation \\ Type of pain \\ Localization \\ Bone conduction of pain \\ Pain with motion \\ Limitation of range of motion \\ Presence of crepitation at site of injury \\ Presence of vascular injury \\ Presence of neurological injury
}

Table IV. Distribution of fractures

$\begin{array}{ll}\text { Fibular } & 7 \\ \text { Bimalleolar } & 4 \\ \text { Calcaneal } & 3 \\ \text { Talar } & 3 \\ \text { Tibial } & 2\end{array}$

of the ankle (12.7 per cent) and $131(87.3$ per cent) soft tissue injuries. The distribution of injuries by age group is seen in Table III. Most patients were under 40 years of age, which may reflect the high proportion of university students in the local population. The distribution of fractures diagnosed is presented in Table $I V$. There was a fairly even distribution of injuries, with fracture of the lateral malleolus being the most common in the series.

Nine of the 24 variables analysed in Tables $V$ and $V I$ appeared to discriminate between soft tissue injury and fracture. These included: 1) age; 2 ) the left or right side; 3 ) the ability to bear weight immediately after injury; 4) a popping or cracking sound at the time of injury; 5) direction of injury; 6) the patient's ability to bear weight on the ankle during the examination; 7) local tenderness; 8) the type of pain present; and 9) bone conduction of pain.

On reassessment of these 9 variables, 5 were eliminated from consideration for further analysis. Statistical analysis in 3 of the 5 variables (the presence of a popping sound at the time of injury, the direction of injury and bone conduction of pain) were often entered as 'unknown'. Thus, these variables may be statistically but not 
Table $V$. Sensitivity analysis for each variable in the history

\begin{tabular}{|c|c|c|c|c|c|}
\hline Variable & Response & Patients & $\begin{array}{l}\% \text { Soft } \\
\text { tissue } \\
\text { injury }\end{array}$ & P-value & $\begin{array}{c}\text { Gain } \\
\text { over } \\
\text { chance } \\
(\%)\end{array}$ \\
\hline \multirow[t]{2}{*}{ Sex } & Male & 75 & $89 \cdot 3$ & 0.461 & $2 \cdot 0$ \\
\hline & Female & 75 & $85 \cdot 3$ & & $2 \cdot 0$ \\
\hline \multirow[t]{2}{*}{ Age } & $\leqq 40$ & 127 & 88.4 & 0.022 & $1 \cdot 1$ \\
\hline & $>40$ & 15 & $66 \cdot 7$ & & $-20 \cdot 6$ \\
\hline \multirow[t]{2}{*}{ Foot } & Right & 71 & 84.5 & 0.038 & $-2 \cdot 8$ \\
\hline & Left & 77 & 90.9 & & $3 \cdot 6$ \\
\hline \multirow{2}{*}{$\begin{array}{l}\text { Manner or } \\
\text { arrival at } \\
\text { hospital }\end{array}$} & With assistance & 58 & $82 \cdot 8$ & $0 \cdot 181$ & $-4 \cdot 5$ \\
\hline & Without assistance & 92 & $90 \cdot 2$ & & $2 \cdot 9$ \\
\hline \multirow{4}{*}{$\begin{array}{l}\text { Ability to } \\
\text { bear weight } \\
\text { Onset of pain }\end{array}$} & Yes & 46 & $78 \cdot 3$ & 0.026 & $-9 \cdot 0$ \\
\hline & No & 104 & 91.4 & & $4 \cdot 1$ \\
\hline & Immediate & 112 & $84 \cdot 8$ & 0.112 & $-2 \cdot 5$ \\
\hline & Delayed & 38 & $94 \cdot 7$ & & $7 \cdot 4$ \\
\hline \multirow{6}{*}{$\begin{array}{l}\text { Popping or } \\
\text { cracking } \\
\text { sound } \\
\text { Mechanism of } \\
\text { injury }\end{array}$} & Present & 52 & $90 \cdot 4$ & 0.048 & $3 \cdot 1$ \\
\hline & Absent & 86 & $88 \cdot 4$ & & $1 \cdot 1$ \\
\hline & Unknown & 12 & $66 \cdot 7$ & & $-20 \cdot 6$ \\
\hline & Fall & 23 & $87 \cdot 0$ & 0.091 & $-0 \cdot 3$ \\
\hline & Twist & 119 & $89 \cdot 1$ & & $1 \cdot 8$ \\
\hline & Blow & 8 & $62 \cdot 5$ & & $-24 \cdot 8$ \\
\hline \multirow{4}{*}{$\begin{array}{l}\text { Direction of } \\
\text { injury }\end{array}$} & Inversion & 98 & $91 \cdot 8$ & 0.022 & 4.5 \\
\hline & Eversion & 11 & 90.9 & & \\
\hline & Other & 15 & $86 \cdot 7$ & & -0.6 \\
\hline & Unknown & 26 & $69 \cdot 2$ & & $-18 \cdot 1$ \\
\hline \multirow{5}{*}{$\begin{array}{l}\text { Time from } \\
\text { injury to } \\
\text { arrival } \\
\text { Activity }\end{array}$} & $\leqq 8 \mathrm{hrs}$ & 83 & $84 \cdot 3$ & 0.220 & $-3 \cdot 0$ \\
\hline & $>8 \mathrm{hrs}$ & 67 & $91 \cdot 0$ & & $3 \cdot 7$ \\
\hline & Athletics & 64 & $92 \cdot 2$ & 0.229 & 4.9 \\
\hline & Climbing & 42 & $81 \cdot 0$ & & $-6 \cdot 3$ \\
\hline & Other & 44 & & & \\
\hline Total & & 150 & $87 \cdot 3$ & - & - \\
\hline
\end{tabular}

clinically significant. The comparison of right or left foot was not used because no determination of right or left sided dominance was made in these patients, and dominance may have a greater influence on the type of injury sustained. The ability to bear weight immediately after the injury was statistically significant but it did not make sense because many of these patients were able to bear weight on the ankle at the time of examination. It does point out the fallacy of ruling out a fracture in a patient who walked on the injured ankle immediately after the accident.

The remaining 4 variables were combined to detcrminc if they would enhance each other in discriminating between soft tissue injury and ankle fracture. Only the combination of the localization of tenderness below the lateral malleolus and the ability to bear weight on the ankle significantly improved $(P<0.005)$ the probability of diagnosing soft tissue injury. The detailed analysis of these 2 variables can be seen in Table VII. Eighty-one patients (54 per cent) had both lateral pain in the ankle and the ability to bear weight on the ankle. Of these patients. 79 ( 97.5 per cent) had soft tissue injuries. While many combinations had high probabilities of diagnosing fractures, this group had the highest increase over chance of diagnosing soft tissue injuries. Other variables, the 'type of pain' or 'age', had high probabilities of separating soft tissue injuries from fractures when considered alone, but did not improve on the results in this combination.

\section{DISCUSSION}

Garfield (1960) suggested that patients under 61 
Table VI. Sensitivity analysis for each variable in the physical examination

\begin{tabular}{|c|c|c|c|c|c|}
\hline Variable & Response & $\begin{array}{c}\text { No. } \\
\text { of } \\
\text { patients }\end{array}$ & $\begin{array}{l}\text { \%Soft } \\
\text { tissue } \\
\text { injury }\end{array}$ & P-value & $\begin{array}{c}\text { Gain } \\
\text { over } \\
\text { chance } \\
(\%)\end{array}$ \\
\hline Ability to & None & 40 & $72 \cdot 5$ & 0.002 & $-14 \cdot 8$ \\
\hline bear weight & Some & 110 & $90 \cdot 0$ & & $2 \cdot 7$ \\
\hline Location of & Lateral & 73 & 89.0 & 0.580 & $1 \cdot 7$ \\
\hline \multirow[t]{3}{*}{ swelling } & Medial & 6 & $83 \cdot 3$ & & $-4 \cdot 0$ \\
\hline & Both & 59 & $88 \cdot 1$ & & 0.8 \\
\hline & None & 12 & 75.0 & & $-12 \cdot 3$ \\
\hline Degree of & Severe & 18 & $77 \cdot 8$ & 0.363 & $-9 \cdot 5$ \\
\hline \multirow[t]{3}{*}{ swelling } & Moderate & 85 & 87.0 & & 0.3 \\
\hline & Slight & 35 & $94 \cdot 3$ & & $7 \cdot 0$ \\
\hline & None & 12 & $83 \cdot 3$ & & -4.0 \\
\hline \multirow[t]{2}{*}{ Ecchymosis } & Present & 45 & $84 \cdot 4$ & 0.500 & -2.9 \\
\hline & Absent & 104 & 88.5 & & $1 \cdot 2$ \\
\hline \multirow[t]{2}{*}{ Laceration } & Present & 6 & $100 \cdot 0$ & 0.339 & $12 \cdot 7$ \\
\hline & Absent & 143 & $86 \cdot 7$ & & -0.6 \\
\hline \multirow{3}{*}{$\begin{array}{l}\text { Location of } \\
\text { pain }\end{array}$} & Lateral & 102 & $92 \cdot 2$ & 0.010 & 6.7 \\
\hline & Medial & $\begin{array}{l}13 \\
31\end{array}$ & $\begin{array}{l}69 \cdot 2 \\
83.9\end{array}$ & & $\begin{array}{r}-18 \cdot 1 \\
3 \cdot 4\end{array}$ \\
\hline & None & 4 & $50 \cdot 0$ & & $\begin{array}{r}-3 \cdot 4 \\
-37 \cdot 3\end{array}$ \\
\hline \multirow[t]{3}{*}{ Type of pain } & Bone & 52 & 75.0 & 0.001 & $-12 \cdot 3$ \\
\hline & Soft tissue & 91 & $95 \cdot 6$ & & $8 \cdot 3$ \\
\hline & Not specified & 7 & $71 \cdot 4$ & & $-15 \cdot 9$ \\
\hline \multirow{4}{*}{$\begin{array}{l}\text { Localization } \\
\text { of pain }\end{array}$} & Point & 52 & $90 \cdot 4$ & 0.614 & 3.1 \\
\hline & Diffuse & 90 & $86 \cdot 7$ & & 0.6 \\
\hline & No pain & 1 & $100 \cdot 0$ & & $12 \cdot 7$ \\
\hline & Not specified & 3 & $66 \cdot 7$ & & -20.6 \\
\hline \multirow{3}{*}{$\begin{array}{l}\text { Bone conduction } \\
\text { of pain }\end{array}$} & Present & 19 & $80 \cdot 0$ & 0.050 & $-7 \cdot 3$ \\
\hline & Absent & 98 & $91 \cdot 8$ & & 4.5 \\
\hline & Unknown & 30 & $76 \cdot 7$ & & $-10 \cdot 6$ \\
\hline \multirow{6}{*}{$\begin{array}{l}\text { Pain with } \\
\text { motion } \\
\text { Limitation of } \\
\text { range of motion }\end{array}$} & Present & 134 & $87 \cdot 3$ & 0.695 & -0.0 \\
\hline & Absent & 12 & $83 \cdot 3$ & & $-4 \cdot 0$ \\
\hline & Deformity & 2 & $100 \cdot 0$ & 0.063 & $12 \cdot 7$ \\
\hline & Pain & 119 & $87 \cdot 4$ & & 0.1 \\
\hline & Not limited & 28 & $89 \cdot 3$ & & $2 \cdot 0$ \\
\hline & Not specified & 1 & 0 & & - \\
\hline \multirow[t]{2}{*}{ Crepitation } & Present & 6 & $100 \cdot 0$ & 0.204 & $12 \cdot 7$ \\
\hline & Absent & 144 & $86 \cdot 8$ & & -0.5 \\
\hline Vascular & Present & 2 & 0.0 & - & - \\
\hline Injury & Absent & $14 \overline{8}$ & $88 \cdot 5$ & & $1 \cdot 2$ \\
\hline Neurological & Present & 3 & $66 \cdot 7$ & - & - \\
\hline Injury & Absent & 147 & $87 \cdot 7$ & - & 0.4 \\
\hline Total & & 150 & $87 \cdot 3$ & - & - \\
\hline
\end{tabular}

years of age with histories of walking injuries and the absence of tenderness, bruising or swelling would not require $X$-ray examination of the ankle. With the exception of age, it was not possible to use his variables to differentiate soft tissue injury from fracture in our population of patients. Older patients may be more likely to sustain fractures from ankle injuries $(33.3 \mathrm{per}$ cent of our patients over 40 years of age had fracture) but only 1 patient in this study was over 61 years of age and she suffered a fracture.

De Lacy and Bradbrooke (1979) reviewed the records of 100 patients with injuries of the ankle and compared them with 93 patients who had fractures of the ankle. Sixty-five per cent of patients with injuries of the ankle had no swell- 
Table VII. Combined analysis of two variables: location of pain and ability to bear weight

\begin{tabular}{|c|c|c|c|c|c|}
\hline Location & $\begin{array}{l}\text { Ability to } \\
\text { bear weight }\end{array}$ & $\begin{array}{l}\text { Patients } \\
\text { with } \\
\text { fracture }\end{array}$ & $\begin{array}{c}\text { Patients } \\
\text { with soft } \\
\text { tissue } \\
\text { injury }\end{array}$ & $\begin{array}{l}\% \text { Soft } \\
\text { tissue } \\
\text { injury }\end{array}$ & $\begin{array}{c}\text { Gain } \\
\text { over } \\
\text { chance } \\
(\%)\end{array}$ \\
\hline Lateral & $\begin{array}{l}\text { None } \\
\text { Some }\end{array}$ & $\begin{array}{l}6 \\
2\end{array}$ & $\begin{array}{l}15 \\
79\end{array}$ & $\begin{array}{l}71 \cdot 4 \\
97.5\end{array}$ & $\begin{array}{r}-15.9 \\
10.2\end{array}$ \\
\hline Medial & $\begin{array}{l}\text { None } \\
\text { Some }\end{array}$ & $\begin{array}{l}2 \\
2\end{array}$ & $\begin{array}{l}3 \\
6\end{array}$ & $\begin{array}{l}60 \cdot 0 \\
75.0\end{array}$ & $\begin{array}{l}-25 \cdot 6 \\
-12 \cdot 3\end{array}$ \\
\hline Equal & $\begin{array}{l}\text { None } \\
\text { Some }\end{array}$ & $\begin{array}{l}2 \\
3\end{array}$ & $\begin{array}{r}9 \\
17\end{array}$ & $\begin{array}{l}81 \cdot 8 \\
85.0\end{array}$ & $\begin{array}{l}-5 \cdot 5 \\
-2 \cdot 3\end{array}$ \\
\hline None & $\begin{array}{l}\text { None } \\
\text { Some }\end{array}$ & $\begin{array}{l}1 \\
1\end{array}$ & $\begin{array}{l}2 \\
0\end{array}$ & $\begin{array}{r}66 \cdot 7 \\
100 \cdot 0\end{array}$ & $-20 \cdot 6$ \\
\hline
\end{tabular}

ing and only 5 had fractures. Ninety-two of the 93 patients with fractures of the ankle had swelling at the fracture site. The authors concluded that the probability of soft tissue injury was 92.3 per cent for patients without swelling and therefore $\mathrm{X}$-ray examination was not necessary. In contrast, only 12 patients in this series were without swelling and their probability of fracture was higher than that of the total population (respectively 25 per cent and 12.7 per cent). The absence of swelling therefore. should not determine whether or not to take $X$-ray films of the ankle.

Brooks et al. (1981) reviewed 241 patients with inversion injuries and concluded that a careful clinical examination was a satisfactory method for differentiating soft tissue injury from fracture. They noted that localized tenderness over the ligaments on the lateral aspect of the ankle without bony tenderness correlated well with the diagnosis of soft tissue injury. They also noted that pain, swelling and bruising were of no help in differentiating soft tissue injuries from fractures. All of their findings concur with the results of this study. While only 98 patients $(65 \cdot 3$ per cent) suffered inversion injuries, 91.8 per cent of them had soft tissue injuries and the presence of bony tenderness was associated with ankle fracture ( 25 per cent).

Brand et al. (1982) conducted a prospective study similar to this one; however, their data are combined in such a way as to make any specific comment about ankle injuries meaningless. In injuries distal to the knee, they found that point tenderness was a helpful determinant whereas in our series, point tenderness was more frequently associated with soft tissue injury ( 34 per cent) than with fractures $(9 \cdot 5$ per cent).

This study demonstrates that it is possible to use ankle radiographs selectively with the expectation of obtaining more positive results without risk to the patient. Patients who came with tenderness over the lateral aspect of the ankle below the malleolus and who could bear some weight on the ankle, did not need $\mathrm{X}$-ray examination. They have a 97.5 per cent probability of having a soft tissue injury $(P<0.005)$.

There are other variables, evident from the study, which should alert the examining doctor to the possibility of fracture despite the fact that they did not statistically alter the previously described results. These variables include: age $>40$ years, history of a blow on the ankle, bony tenderness or bone conduction of pain.

While it is impossible to expect that all patient populations will be similar to this one, these results provide determinants which others may adopt selectively to eliminate the need for X-ray examination in patients with acute injuries of the ankle. In our population, adherence to the indications described would decrease the number of unnecessary $X$-rays by 54 per cent without risk to the patients.

\section{Acknowledgements}

We would like to thank the residents and staff of the Emergency Treatment Centre at the University of Iowa Hospitals and Clinics for their help in collecting the data for this study and $\mathrm{Mr}$ T. Blommers and Ms P. Piper for their assistance in preparing this manuscript. 


\section{REFERENCES}

Brand D. A., Frazier W. H. and Kohlhipp W. C., (1982) A protocol for selecting patients with injured extremities who need X-rays. N. Engl. J. Med. 306, 333.

Brooks S. C., Potter B. T. and Rainey J. B. (1981) Inversion injuries of the ankle: clinical assessment and radiographic review. Br. Med. J. 1, 607 . de Lacey G. and Bradbrooke S. (1979) Rationalizing requests for $\mathrm{X}$-ray examination of acute ankle injuries. Br. Med. J. 1, 1587.

Garfield J. S. (1960) Is radiological examination of the twisted ankle necessary? Lancet 2, 1167.

Stother I. G. (1974) Incidence of minor fractures in twisting injuries of the ankle. Injury 5, 213.

Paper accepted 26 May 1982.

Requests for reprints should be addressed to: Dr T Vargish. Department of Surgery, West Virginia University Medical Center. Morgantown, West Virginia 26506.

\section{INTERNATIONAL TRAUMA FOUNDATION MAY EDEN PRIZE ESSAY COMPETITION}

The above prize of $£ 500$ will be awarded to the Medical Practitioner(s) who submits the most meritorious paper to this competition. The paper should be an unpublished work describing original investigations, observations or techniques that have substantially contributed to the improvement in the early care of the seriously injured.

Closing date for entry: 30 June, 1983.

Further information may be obtained from Mr. James Ruff, Operations Adviser, International Trauma Foundation, 21 West Smithfield, London EC1A 9HY. 